\title{
Portuguese Higher Education Graduates' Views on Academic Writing
}

\author{
Maria L. Cabral ${ }^{1, *}$ \\ ${ }^{1}$ Faculty of Human and Social Sciences, University of Algarve, Gambelas Campus, 8005-139 \\ Faro, Portugal \\ *Corresponding author: Faculty of Human and Social Sciences, University of Algarve, \\ Gambelas Campus, 8005-139 Faro, Portugal. Tel: 351-917-770-140. E-mail: \\ mcabral@ualg.pt
}

Received: November 11, 2019 Accepted: February 12, 2020 Published: March 6, 2020

doi:10.5296/ije.v12i1.16625 URL: https://doi.org/10.5296/ije.v12i1.16625

\begin{abstract}
This paper examines the language choices and the process of academic writing of a group of 35 Portuguese graduate students in the fields of humanities and social sciences with the aim of illustrating their language preferences, as well as the aspects they take into consideration while writing either in Portuguese or in English.

Results of this study indicate that the participants prefer to write their papers in Portuguese, their first language, and that they use similar approaches when writing in both languages. However, findings also reveal they are concerned with slightly different process aspects when composing and revising their texts in Portuguese and in English. These differences seem to be associated with acquired discourse traditions in Portuguese language, as well as with the participants' lower competence in English language writing.
\end{abstract}

Keywords: L1 and FL writing, composing in two languages, revising in two languages 


\section{Introduction}

Writing is a major competence through the formal education process and it has always been considered the utmost challenge to students at any school level. Particularly in undergraduate and graduate programmes, in which writing constitutes a privileged means for students' assessment, its challenge is added to by the requirements of specific academic genres that most students have not yet acquired. For all these reasons, writing assumes the highest relevance for students as well as for teachers, throughout the schooling process.

In Portugal, at the initial years of schooling, students are taught the letter sound correspondence, and most of what they do in school is copying or transcribing others' texts. Later, during middle and secondary schooling, their native, as well as their foreign language syllabi require them to compose texts on different topics. Nevertheless, as a rule, students do not write them while in the language classrooms. More than often these texts are assigned for homework, where supervision may be scarce or, in the best-case scenario, available from parents, siblings or friends.

The teaching practices in Portuguese middle and secondary schools have long been criticized by a few scholars (for example: Santos, 1994; Cabral, 1994; 2004a; 2004b; 2010). However, and despite the numerous educational reforms which have attempted to motivate teachers to adopt process or genre approaches to the teaching of writing, my long experience as a middle and secondary school language teaching supervisor, tells me that little has in fact changed in the language classrooms when writing is the issue in question.

Still today, my university students report that they were not really taught to write during their previous school years. The ones that are proficient writers usually say that they write well because they read a lot, and mostly just because they simply love to write. In my English writing class this school year, only some out of my 44 first year undergraduate students could write acceptable texts on different topics. Most of them exhibited difficulties in planning their texts according to the communicative objectives previously set by themselves, and the activity of revising their texts more than often resulted in complaints for they considered that a 'tedious' task.

When asked about their past writing experiences in language classrooms, my first year university English language students stated that they did not have much experience in writing texts and that the writing activities they were asked to complete at the $12^{\text {th }}$ grade, either in English or in Portuguese, were mostly done as homework, and included, for example, summarizing ideas from texts, written answers to reading comprehension exercises, short descriptions and short narratives to demonstrate knowledge of reading assignments, as well as short texts (25 to 30 lines) stating their opinions on subject matter topics. All their writings had their teachers as their intended audience (Cabral, 2018).

This paper concerns the second phase of a larger descriptive study, which previously inquired the subject of academic writing in Portuguese Universities (Cabral, Costa \& Nobre, 2016). The first phase examined aspects of the process of academic writing of Portuguese university professors. Later, graduate students were also inquired about their awareness of their writing 
competences and favourite composing strategies. The goal of the present study is to describe the students' writing self-portrait, as well as to identify their favourite procedures when writing either in the Portuguese or the English language. Participants were also inquired about their representations of their teachers' writing evaluation criteria.

It is my belief that the knowledge of the students' language profile as well as of their favourite composing strategies is a relevant tool for teachers who design language tasks that aim to meet the students' learning needs. This study was therefore guided by the following research questions:

- What are the students' perceived languages and writing competences?

- What language do they write their academic papers in?

- What criteria do they think is used by their professors in evaluating their written papers?

- What parameters of the writing process do they consider while writing their academic papers?

\section{Writing in Portuguese Schools}

Portuguese students are taught in Portuguese, and even though most of them chose English as their first foreign language at $5^{\text {th }}$ grade, their writing competences are mainly developed in Portuguese, their first language, throughout their schooling process.

Neither the Portuguese language nor the English language basic and secondary school curricula include a specific subject dedicated to writing. Although writing is considered a relevant skill in the curricula, the syllabi of both languages state that the acquisition of writing skills and abilities should occur while the student performs different language tasks in the classroom, with the aim of developing their overall communicative competence.

The Portuguese Language syllabi for the $9^{\text {th }}$ grade states that students who complete that final year of middle school should be able to:

- Plan and revise their own texts;

- Plan and summarize expository and argumentative short texts;

-Write to express knowledge, answer questions and follow instructions. (Buescu et al, 2015:36):

The Portuguese Language syllabus for the Secondary School years $\left(10^{\text {th }}, 11^{\text {th }}\right.$ and $12^{\text {th }}$ grades $)$, states that by the end of their secondary Portuguese language education, students should be able to:

- Synthetize texts they have read;

- Compose expository texts;

- Compose critical analysis of literary texts; 
- Compose opinion texts. (Buescu et al, 2014:34).

The analysis of the writing objectives listed on the English language syllabi for basic and secondary schools shows that from the $10^{\text {th }}$ grade onwards (after 5 years of learning EFL) students are expected to gradually acquire the ability to write longer and more complex texts, which should require composing, mainly knowledge telling or retelling, but also knowledge transforming (Grabe \& Kaplan, 1996: 4). The $12^{\text {th }}$ grade EFL syllabus states that at the end of the schooling process, Portuguese EFL students are expected to:

- Write well-structured texts showing clarity, fluency, focusing on their communicative intention and on the audience;

- Write texts focusing on the content topics of the syllabus showing that students have integrated their own experience as well as knowledge acquired in other subjects of their curriculum;

- Demonstrate the ability to relate, to synthesize in a coherent and logic way, and to emphasize the most relevant aspects of different sets of given information in a text;

- Elaborate texts on complex topics, while showing the ability to develop consistent and well-supported arguments. (Programas de Inglês, 2001-2003:17).

Although the basic and secondary language curricula clearly aim at the development of the students' general writing skills and abilities, the longer writing activities that students do in language classrooms include two - to three - paragraph texts, following a given introduction-body-conclusion text-model. I. e., writing activities in class do not have the development of writing as knowledge transforming as a goal, and as such, the writing acts students perform do not "constitute a heuristic through which an information-transfer problem is solved both for the author and for his or her intended audience" (Grabe \& Kaplan, 1996:5).

In the case of higher education, academic writing is not also a common subject in most degree programmes of the Portuguese $1^{\text {st }}$ cycle of higher education studies (equivalent to bachelor's degree), and only graduate programmes at Portuguese Universities ( $2^{\text {nd }}$ cycle of studies - equivalent to master's degree) have recently started to include specific Portuguese language academic writing courses. There is a specific curricular unit dedicated to academic writing in the graduate (master's) programmes at the Universities of Algarve, Evora, Lisboa, Minho, Católica, Porto and UTAD, but in other higher education institutions academic writing is usually a topic on the syllabus of curricular units dedicated to the teaching of research methods and procedures.

An examination of the assessment requirements included in the Academic Writing syllabi published online by Portuguese universities indicates that students are often required to write short essays (trabalhos escritos), participate in sections of their supervisors' scientific papers (artigos científicos), and in the case of $\mathrm{PhD}$ programmes students are required to write reports and research proposals.

Just like in any other university programme, Portuguese graduate students are required to 
write essays, literature reviews on scientific phenomena, scientific reports and dissertations or theses at the final years of their graduate courses. These students' writings have always been completed under the guidance of the different scientific subjects' professors or supervisors, and this is still the common practice in most Portuguese higher education institutions.

\section{Academic Writing}

Commonly accepted as "any writing produced in and for the academy," (Nelson \& Castelló, 2012), academic writing has long become a study subject in many higher education institutions across the world with the aim of familiarizing the students with a genre that requires the domain of scientific terminology, as well as the knowledge of a specific text organization and structure designated as 'scientific paper'.

Although today most of the scientific publications are written in English, Academic Writing in the English language is not yet included as a mandatory course in most of the humanities and social sciences graduate degrees at the Portuguese Universities. Academic Writing is, in some cases, listed as content on the English Language undergraduate syllabi and, as such, it is treated as one item among many others throughout the language teaching process.

Academic writing, in abstract terms, is usually defined as a process of composing a text using a formal voice and the appropriate style with the aim of sharing theories or research evidence with a specific research community. However, the truth is that the apparent simplicity of composing a text having these goals in mind can become a difficult task for many students around the world, particularly when the text is to be written in a foreign language. Furthermore, whether one writes in his/her own language (L1) or in a second or foreign language (L2/FL), the act of composing a text for academic purposes is much more demanding than writing a text for personal or social reasons.

In graduate programmes, students are required to write short essays and papers on topics of their own fields of studies, and to do so, adequately and appropriately, students must have different kinds of knowledge and skills. Firstly, students need to be familiar with the topic they have chosen to write about, and they also need to be able to identify the characteristics of the genre they are going to adopt when composing their texts. Then, they must have a solid command of the language they have chosen to use, including the abilities to plan and compose their text accordingly to their individual writing goals.

Consequently, academic writing, in any language, is always a complex task. In fact, the complexity of writing comes from a relation of interdependence created amongst several entities: the writer, the topic, the contexts of text production and reception, the text and its intended audience. Furthermore, because every text "is much more than the generation of text-linguistic products" Candlin \& Hyland (1999:2), a written text is not only an individual product but also a result of the writer's knowledge and experience and, at the same time, its meaning is shaped by the history and the culture of the discourse community where the writer is integrated. 
It is assumed that a reflection on academic writing must always begin by considering that language proficiency - including vocabulary, spelling, grammar and syntax - plays a central role in writing competence, particularly if we are talking about writing in a L2/FL language. Genre knowledge (Gabrialatos, 2002; Roca de Larios et al., 2008), writing strategies (Lu, 2010), reading competence (Gradman \& Hanania, 1991; Lee, Krashen, \& Gribbons, 1996; Lee \& Krashen, 1996: Lee, 2001; Krashen, 2014) as well as L1 composing strategies (Krashen \& Lee, 2002) are also other most relevant dimensions when we talk about foreign language writing.

In everyday life, a speaker chooses a language to communicate on the grounds of his own language repertoire, his own motivations as well as the requirements of the task at hand. When enrolled in a language university programme, students need to respond to their courses' requirements, and, as such, their language choice is primarily dictated by the need to complete their academic tasks. They will have to write in the language they are supposed to write in a specific course. Therefore, their language competence as well as their attitudes and motivation towards the target language and culture may also play a role in the quality of the text they are expected to compose. Much of what a language student does at university involves academic writing. Students use writing to take notes during presentations or when researching a topic, and they are also constantly required to compose different types of essays or research reports, with the aim of preparing them to complete their academic degrees.

Whatever the writing task students must accomplish, the activity of writing itself has to be conceived as a complex process of meaning construction. Besides targeting a specific audience, the writer must consider the need for clarity, as well as the selection of a consonant mode for building the text (Amor, 1993: 112). When, within the context of academic writing, students are asked to produce longer than regular classroom texts (written answers to reading comprehension questions, short summaries, essays, etc.), they usually do it with the aim of fulfilling a research task, or an essay on some mandatory topic. In either case, writing is always a daunting challenge for them since, besides the difficulties inherent to composition itself, they have also to demonstrate knowledge of the appropriate genre.

If writing a paper is a challenge for language students, that challenge becomes even greater when it must be written in a foreign language, not normally used to communicate (e.g., Flowerdew, 2001; Siguan, 2001; Gosden, 2003; Belcher, 2007). Indeed, as Swales (2002) reminds us, writing academic papers is a heavy burden for non-native speakers of English, and this burden becomes even greater when the author is not highly proficient in English, the language $\mathrm{s} / \mathrm{he}$ intends to use.

Researchers have defended that there is a relationship between language proficiency and text quality (e.g., Sasaki \& Hirose, 1996; Sasaki, 2002; Beare \& Bourdages, 2007; Manchon \& de Larios, 2007; López-Urdaneta, 2011) and that there are similarities in the L1 and L2 writing processes of proficient L2 speakers, since they adopt similar rhetorical patterns (e.g., Uysal, 2008), as well as similar strategies while planning, composing and revising their texts either in L1 or in L2 (e.g., Matsumoto, 1995, Zainuddin \& Moore, 2003; Kliber, 2010). Kern (2000:177), based on Krapels (1990) and Silva’s (1993) studies, suggests that 
(...) both first and second language writing involves essentially similar processes, but that second language writing is complexified by the addition of new resources and norms. Learning the structural elements of the new language, new rhetorical conventions, and perhaps even new uses of writing does not replace, but is added to what one already knows about writing from one's native language.

Other researchers have, however, pointed to differences between L1 and L2 composing activities, namely in the process of goal setting and content generation (e.g., van Weijen, et al., 2009; de Larios, et al., 2006), in the amount of text planning (eg., Silva, 1993; Manchon $\&$ de Larios, 2007), and in revising procedures (e.g., Casey, 2006). More recently, Wang (2012) reviewed published literature focusing on the differences in L1 and L2 academic writing, concluding that there are "differences between academic writing in L1 and L2 in various aspects (...): in the level of lexicon, (...) in the level of sentence, and (...) in the level of passage" (Wang, 2012, p. 640).

A review of research studies, as well as of textbooks and recommendation booklets published on the topic of academic writing indicates that authors and institutions usually dedicate attention to aspects that advanced writers should take into consideration while composing and revising their texts in L1 or in L2/FL (e.g., Raimes, 1985; Connor, 1988; Grabe \& Kaplan, 1996; Trible, 1996; Swales, 2002; Ritter, 2005; Swales \& Feak, 2006; Becker, 2007; Peironcely, 2008; Tang, 2012; University of Essex, 2012; University of Bristol 2012, 2014; University of Wisconsin, 2014).

Firstly, academic writing is thought to more rigidly follow rules of convention than other types of writing. Cohesion, for instances, requires that writers observe the appropriate contextualized tense uses and other discourse frames which lead to the production of written texts that 'adhere to the conventions of writing in English" (Hinkel, 2002:193). Then, academic texts are also usually more brief and concise than other writing genres, which require writers to pay attention to the need to use a more formal, more objective and less redundant text.

In this study, 35 Portuguese students were inquired about aspects of their own writing process, either in English or in Portuguese language. They were also asked to think of the writing aspects that might be valued by their professors when their texts are evaluated.

\section{Method}

This study was guided by the following research questions: A) What are the students' perceived languages and writing competences? B) What language do they write their academic papers in? B) What criteria do they think their professors use when evaluating their written papers? C) What parameters of the writing process do they consider more relevant while revising their academic papers? D) What words best describe their concerns when writing in Portuguese as well as in English?

Informed by idiographic research principles, the present study follows the same 
methodological design of a previous study done with similar aims (Cabral, Costa \& Nobre, 2016), and uses similar data collection and data treatment procedures.

\subsection{Participants}

An email invitation was sent to the school email addresses of 150 humanities and social sciences graduate students at the state University of the Algarve. 35 graduate students within an age range from 20 to 50 years old accepted the invitation and voluntarily responded to a questionnaire.

The sample was composed of 24 female and 11 male students. The largest group of respondents were female students (42\%) in the age range 21-30 years old, who were enrolled in Social Sciences graduate programmes (Table 1).

Table 1. Characterization of Participants (N 35)

\begin{tabular}{llc}
\hline & & N of Graduate Students \\
\hline \multirow{2}{*}{ Field of Studies } & Language Sciences & 6 \\
& Social Sciences & 29 \\
Sex & Male & 11 \\
& Female & 24 \\
\multirow{2}{*}{ Age } & $20-30$ yrs old & 15 \\
& $31-40$ yrs old & 12 \\
& $41-50$ yrs old & 8 \\
\hline
\end{tabular}

\subsection{Instruments}

The online questionnaire built for this study included 10 questions in English language: 4 multiple choice questions and 4 Likert scale questions aimed at the characterization of the participants, the identification of their language preference when writing academic papers, their English language competence, their intuitions on the parameters valued by their professors in the process of evaluating their papers, and their own opinions on what matters to them while in the writing process. The questionnaire also included 2 open ended questions aiming at the identification of the criteria participants take into consideration while writing academic papers in Portuguese and in English. The questionnaire was built using Survey Monkey, an online survey provider (https://www.surveymonkey.com). Its final version included the revisions suggested by three university professors, who evaluated previous draft samples of the survey questions. Table 2 demonstrates the correspondence between the research questions and the questions included in the questionnaire applied to respondents. 
Table 2. Correspondence between Research and Questionnaire Questions

\begin{tabular}{|c|c|}
\hline Research Questions & Questionnaire Questions \\
\hline $\begin{array}{l}\text { A) What are the students' } \\
\text { perceived languages and writing } \\
\text { competences? }\end{array}$ & $\begin{array}{l}\text { 1. Nr of years of EFL in basic/secondary school } \\
\text { 2. Did you learn how to write academic papers in } \\
\text { English? When? } \\
\text { 3. What is your English language competence? }\end{array}$ \\
\hline $\begin{array}{l}\text { B) What language do they write } \\
\text { their academic papers in? }\end{array}$ & $\begin{array}{l}\text { 4. What language do you prefer to write your papers in? } \\
5 . \text { What language do you usually use when writing } \\
\text { academic papers? }\end{array}$ \\
\hline $\begin{array}{l}\text { C) What criteria do they think is } \\
\text { used by their professors in } \\
\text { evaluating their written papers? }\end{array}$ & $\begin{array}{l}\text { 6. Which of the following parameters do you think your } \\
\text { professors pay more attention to when evaluating your } \\
\text { writing? }\end{array}$ \\
\hline $\begin{array}{l}\text { D) What parameters of the } \\
\text { writing process do they consider } \\
\text { while writing their academic } \\
\text { papers? }\end{array}$ & $\begin{array}{l}\text { 7. Which of the following recommendations do you } \\
\text { consider more important when composing in Portuguese } \\
\text { and in English? } \\
\text { 8. What importance do you usually attribute to the } \\
\text { following dimensions while revising academic texts? } \\
\text { 9. What are the first three words that come to mind to } \\
\text { describe your concerns regarding the writing process in } \\
\text { English? } \\
\text { 10. What are the first three words that come to your mind } \\
\text { to describe your concerns regarding the writing process } \\
\text { in Portuguese? }\end{array}$ \\
\hline
\end{tabular}

\subsection{Procedures}

Data were collected online using The Survey Monkey website. Data collected and organized by the Survey Monkey website tools were then retrieved and further treated with the help of an Excel matrix. Data collected through the multiple-choice questions were treated with the computation of the total choice frequencies for each item and the corresponding percentages. Data collected with the rank order question were examined in order to determine the respondents' preference for each item. The first item chosen by respondents (ranked as \#1) was attributed three points, the second item chosen (ranked as \#2) was attributed two points, and the last item chosen (ranked as \#3) was attributed one point. After the computation of the mean of the total points attributed to each item, the largest average obtained corresponds to the most preferred choice by the respondents.

A thematic analysis technique was used to treat collected qualitative data obtained with answers to questions 9 and 10. Text coding procedures were developed as follows: the respondents' answers were transcribed and systematically read in search for the emergence of 


\section{Macrothink

relevant common thematic units representing the communality of the participants' voice on the topics of inquiry. Similar thematic units (text units) found were grouped under categories labelled accordingly to the topics of inquiry (Anderson, 2007). The categories built for the text analysis were:

- Grammar and lexis

- Textual organization

- Discourse

- External aspects

The analysis of the text units (words chosen by participants) and the corresponding labelling process were subject to a process of intercoder agreement performed by three independent judges (average percent agreement 83.3\%). Text units were then counted to identify the number of occurrences associated with each unit grouped under the different categories. Categories and text units associated were then displayed in graphic representations (Figures 6, 7 and 8) as to better illustrate the frequency of their occurrence in the respondents' texts.

\section{Results and Discussion}

This section focuses on the analysis of the data obtained from the participants' answers to the questionnaire, which then allow us to answer the research questions that guided this study. Results and their discussion are organized under the respective research question.

\subsection{What are the Students' Perceived Languages and Writing Competences?}

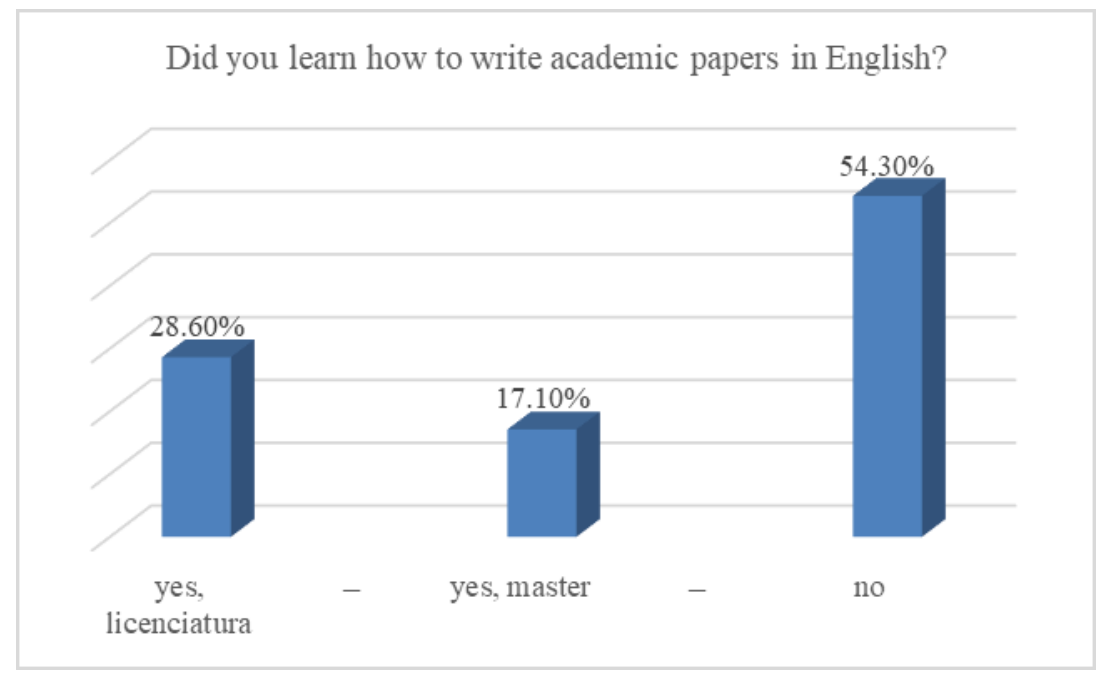

Figure 1. Were you Taught to Write Academic Papers in English? When? 


\section{Al Macrothink Institute ${ }^{\mathrm{TM}}$}

The majority (25) of the group of 35 inquired Portuguese graduate students informed that they studied English for 5 years in secondary school, while ten of them stated having studied it for 7 years. When asked if, and when they were taught to write in English, their answers indicated that the majority (19) were not taught to write in English. Ten participants stated they learned it while undergraduate students and only six stated that they learned how to write academic papers in English at the graduate programmes they had just completed (Figure 1). Although all respondents graduated with success from secondary school, and 25 stated they studied English for at least 5 years, more than $50 \%$ of the respondents informed that they did not learn academic writing before coming to the university.

In fact, their representations of their own English language competence indicate that only 10 of the 35 participants consider themselves highly competent in English (advanced level), while 21 state that they think they are at an intermediate level of English language competence. Despite the number of years they studied English, four of them admit they are still beginners.

\subsection{What Language Do They Write Their Academic Papers in?}

The first questions inquired the participants about which language they usually adopt when they must write papers for academic purposes. Their answers indicate that most of them 'always' write in Portuguese (17 out of 35) and only five say that they 'always' write in English. Thirteen participants say that they 'frequently' write in Portuguese and ten say they 'frequently' write in English (Figure 2). When asked which language they would prefer to use when writing, thirty they said they would rather write in Portuguese, and only five stated that they would choose English when writing academic papers. The participants who indicated their preference for English writing are the ones who completed a longer English language education in secondary school ( 7 years or more).

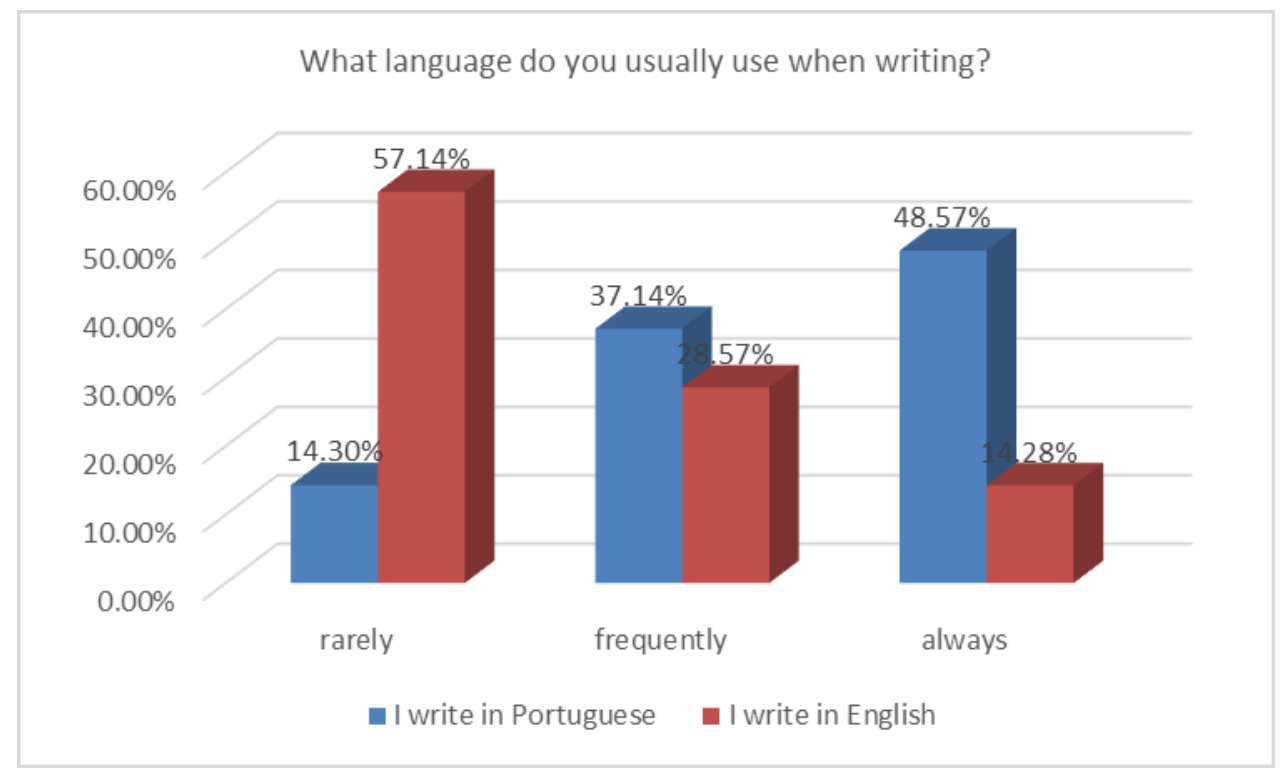

Figure 2. Language Used to Write in Academy (N 35) 
5.3 Which of the Following Parameters Do You Think Your Professors Pay More Attention to When Evaluating Your Writings?

Research on students' reactions to their teachers' evaluation feedback on their texts demonstrates that students consider it an effective tool to improve their own ability to write academic texts (Tom, Morni, \& Metom, 2013). On the assumption that Portuguese higher education students have also developed the ability to interpret their professors' feedback on their written texts, the participants of this study were asked what assessment parameters they thought were considered more relevant when their texts were evaluated. A list of parameters was then presented to the participants and they were asked to choose the ones they thought their professors pay more attention to.

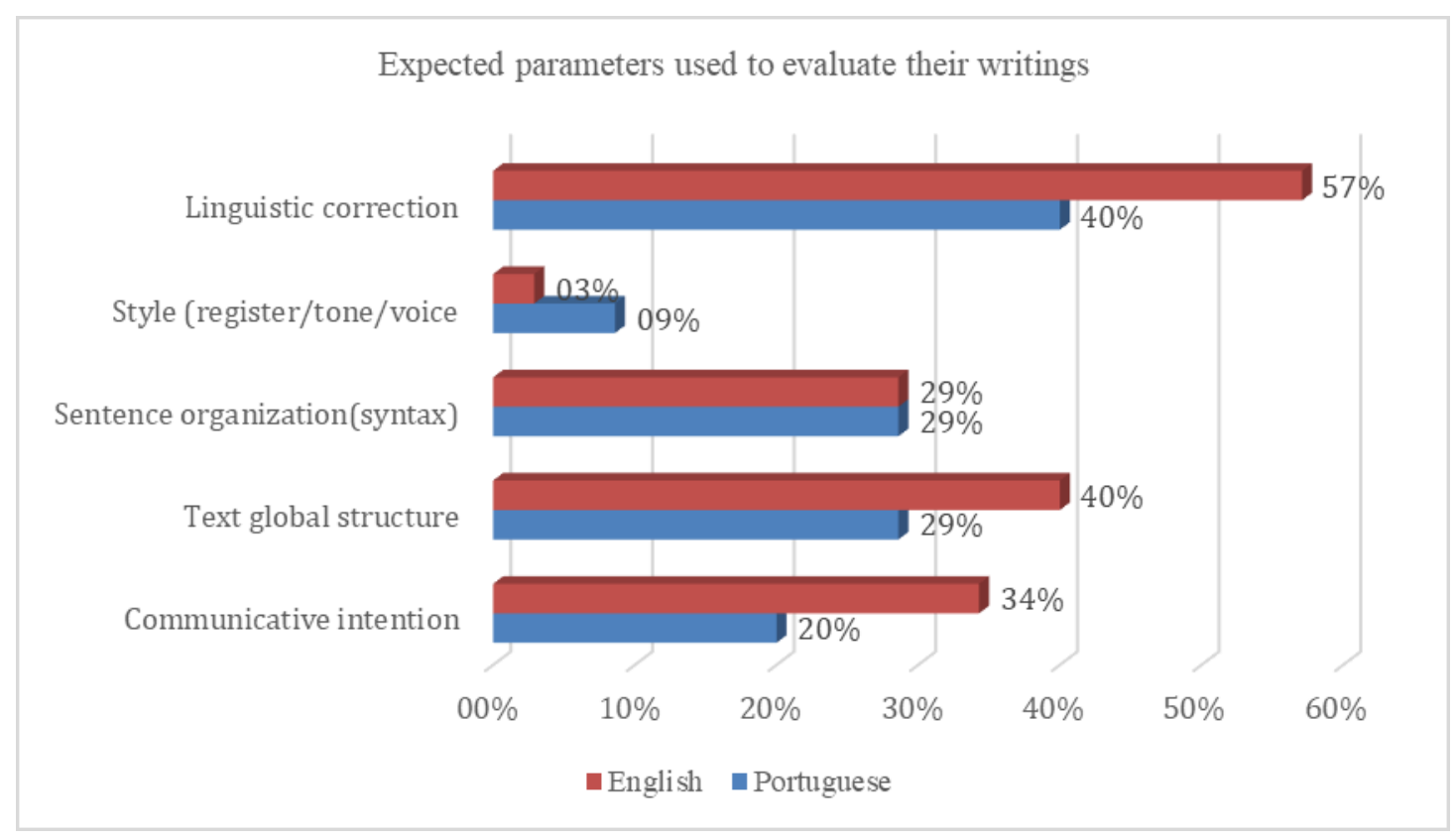

Figure 3. Writing Assessment Parameters Expected to be Valued by University Professors (N 35)

Figure 3 shows the participants' answers for their Portuguese as well as their English writing evaluation. Twenty respondents think that 'Linguistic correction' is the highest concern for English Language professors while they evaluate their writings. The same parameter is viewed as being the most valued parameter for Portuguese language professors by 14 participants. 'Text global structure' was considered a higher priority for English professors by 14 respondents while only 10 of them considered it to be highly important for Portuguese professors. Ten participants think that 'Syntax' is equally valued by both language professors. 'Style, register/ tone and voice' are viewed as being more valued by Portuguese language professors than by English language professors, although this parameter was only mentioned by a few number of respondents ( 1 for English and 3 for Portuguese writing evaluation). That is, for the larger number of the respondents, the most important parameters in English language writing assessment is "Linguistic correction", followed by "Text global structure", 


\section{Ml Macrothink}

International Journal of Education

ISSN 1948-5476

2020, Vol. 12, No. 1

"Communicative intention", "Syntax" and "Style, register/ tone and voice'. Portuguese professors, on their turn, are also though to highly value "linguistic correction", followed by "text global structure" and 'syntax'. More than $90 \%$ of the participants also think that "Style, register/ tone and voice' do not represent a great concern for Portuguese or English professors when they are assessing their student's tests.

5.4 Which of the Following Recommendations do you Consider When Composing Your Texts in Portuguese and in English?

Participants were also inquired about their own process of composing in English as well as in Portuguese. A list of 'recommendations' was presented to them, and they were asked to choose the ones they considered more important while in the process of composing their texts in English and in Portuguese. Figure 4 shows their answers to these questions. 'Avoidance of subjective discourse/personal feelings' was the recommendation most valued by participants, when in the process of writing in English (45,7\%) and in Portuguese $(48,6 \%)$, followed by the recommendation to observe the 'canonical structure of the scientific texts' - $40 \%$ valued that when writing in English, and 37,1\% when writing in Portuguese. The 'avoidance of frills, rhetorical figures and qualifiers' was said to be more relevant while writing in Portuguese (40\%) rather than in English writing (31,4\%). Nevertheless, the adoption of 'simple sentences and active voice' was considered more important when composing in English (48\%), rather than in Portuguese $(28,6 \%)$. On the contrary, 'Focusing on the audience' was considered more relevant for Portuguese language writing (40\%) than for English language writing $(31,4 \%)$.

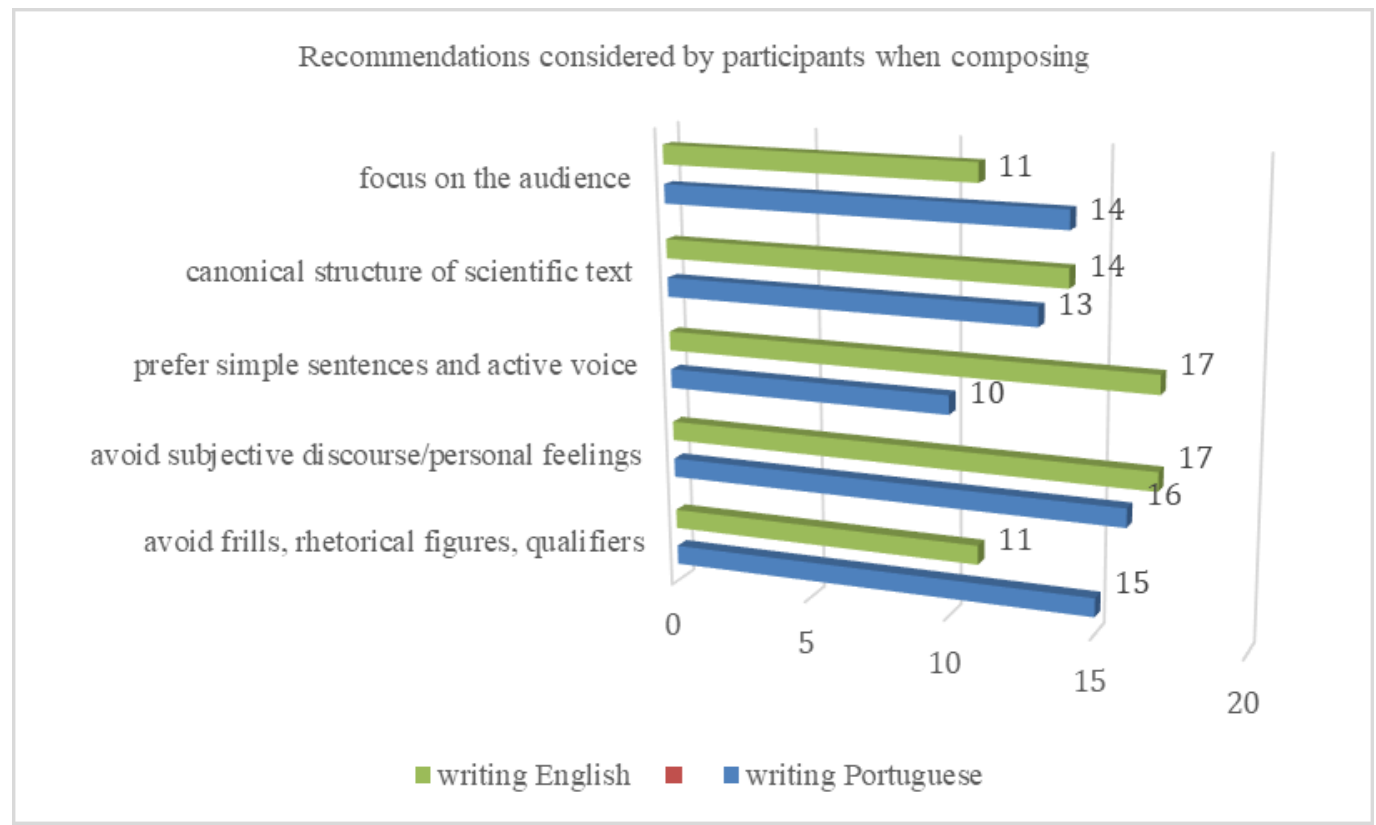

Figure 4. Recommendations Considered by Participants While Composing Their Texts 


\section{Macrothink}

That is, the participants of this study seem to have in mind somewhat similar recommendations when they write in Portuguese as well as in English, although some aspects are more frequently mentioned than others when they refer to Portuguese or to English language writing. On one hand, 'Avoidance of subjective discourse and personal feelings' and 'Avoidance of frills, rhetorical figures and qualifiers' are the most frequently mentioned recommendations when participants focus on their writing in Portuguese, followed by 'Focus on the audience" and the observation of the 'Canonical structure of scientific texts'. The least considered recommendation is the 'Preference for simple sentences in active voice". On the other hand, they say that 'Avoidance of subjective discourse and personal feelings' and 'Preference for simple sentences in active voice' are the recommendations they mostly equally evoke when they are in the process of composing in English language. Next, they pay attention to the 'Canonical structure of scientific texts', and then they think about the need to 'Avoid frills, rhetorical figures and qualifiers' and about the 'Focus on the audience'.

5.5 What Importance Do You Attribute to the Following Dimensions While Revising Your Academic Texts?

Participants were further inquired about other aspects they might consider important while in the process of revising their own texts in both languages, before submitting them to evaluation. They were required to rank the following sets of dimensions presented to them as either 1- more important, 2- medium important, or 3 - less important.

Table 3. Several Sets of Dimensions

\begin{tabular}{lll}
\hline & Several sets of dimensions & \\
\hline $\begin{array}{l}\text { Text global planning, genre, } \\
\text { style, format }\end{array}$ & $\begin{array}{l}\text { Revising sentence structure, } \\
\text { linguistic correction }\end{array}$ & $\begin{array}{l}\text { Topic choice, research } \\
\text { information }\end{array}$ \\
\hline
\end{tabular}

Figure 5, shows the participants choices concerning the importance attributed to the aspects presented to them. 


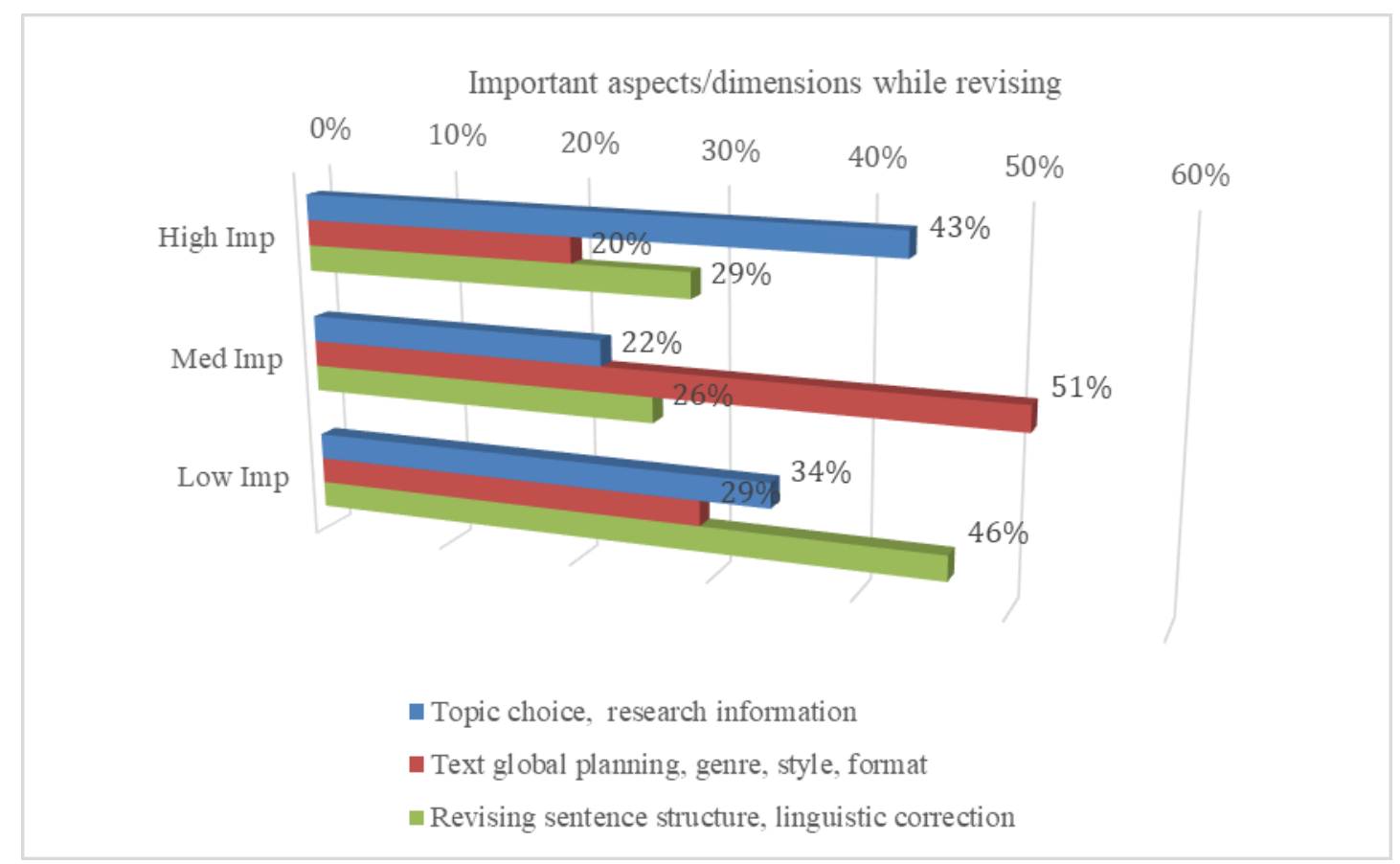

Figure 5. Value Attributed to Dimensions of the Revising Process in Both Languages

'Topic choice, research information' was considered the most important dimension while revising academic texts in English or in Portuguese language by 15 participants. Other 8 participants considered it of medium importance and 12 indicated that they consider it a low important dimension when they revise their academic texts. Ten participants considered 'Revising sentence structure and linguistic correction' to be highly important. Nine considered it of medium importance and 16 indicated that 'Revising sentence structure and linguistic correction' were of low importance to them while revising their own texts. 'Text global planning, genre, style and text format' were the least classified as high important dimensions for 7 participants. However, 18 respondents considered them as medium important, and 10 considered them of low importance in the revising process.

5.6 What are the First Three Words That Come to Your Mind to Describe Your Concerns Regarding the Writing Process in English as well as in Portuguese?

The last two questions of the questionnaire aimed at the identification of the students' own words when asked to describe their concerns while writing academic papers in English as well as in Portuguese. By requesting the participants' own opinion on their writing process, without any hints that might guide their answers, I expected to better understand what they really thought about their own writing process, weather in English or in Portuguese. The students' answers were listed and similar words (text units) were grouped together under each of the categories that emerged from the analysis of the words indicated. Table 4 shows the category matrix used to display text units revealed on the participants' answers to the topics of inquiry, indicating whether they occurred $(\checkmark)$ or not $(x)$ when participants referred to either the Portuguese language or the English writing processes, or both. 
Table 4. Categories and Text Units

\begin{tabular}{|c|c|c|c|}
\hline Categories & Text units & $\begin{array}{l}\text { Writing in } \\
\text { Portuguese }\end{array}$ & $\begin{array}{c}\text { Writing in } \\
\text { English }\end{array}$ \\
\hline \multirow{5}{*}{ Grammatical and lexical dimensions } & Fluency & $\checkmark$ & $\checkmark$ \\
\hline & Orthography & $\checkmark$ & $\checkmark$ \\
\hline & Punctuation & $\checkmark$ & $x$ \\
\hline & Syntax & $\checkmark$ & $\checkmark$ \\
\hline & Vocabulary & $\checkmark$ & $x$ \\
\hline Organization dimensions & text structure & $\checkmark$ & $\checkmark$ \\
\hline \multirow{11}{*}{ Discourse dimensions } & Aesthetics & $x$ & $\checkmark$ \\
\hline & Ambiguity & $\checkmark$ & $x$ \\
\hline & Audience & $\checkmark$ & $\checkmark$ \\
\hline & Clarity & $\checkmark$ & $\checkmark$ \\
\hline & coherence/cohesion & $\checkmark$ & $\checkmark$ \\
\hline & Context & $\checkmark$ & $\checkmark$ \\
\hline & Intention & $\checkmark$ & $\checkmark$ \\
\hline & Objectivity & $\checkmark$ & $\checkmark$ \\
\hline & Redundancy & $x$ & $\checkmark$ \\
\hline & Register & $x$ & $\checkmark$ \\
\hline & style/tone & $\checkmark$ & $x$ \\
\hline \multirow{3}{*}{ External dimensions } & teachers' evaluation & $\checkmark$ & $\checkmark$ \\
\hline & scientific correction & $\checkmark$ & $\checkmark$ \\
\hline & topic choice & $x$ & $\checkmark$ \\
\hline
\end{tabular}

The following graphs demonstrate the participants' 3 first words used to best describe their concerns when writing their papers in English (Figure 6) and in Portuguese (Figure 7).

Words describing concerns in English writing

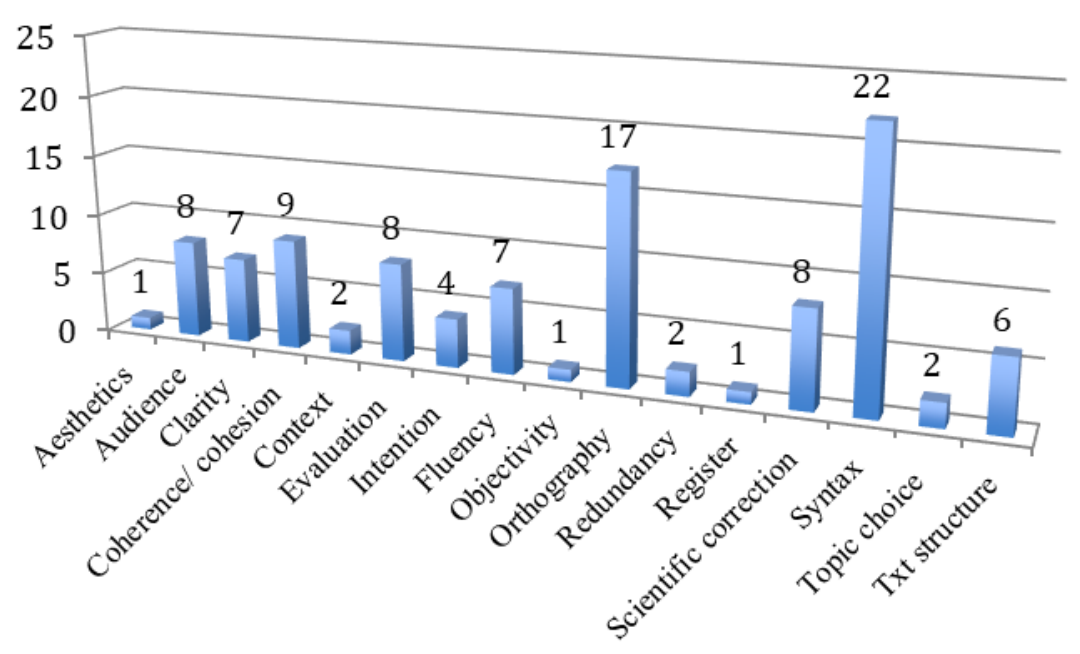

Figure 6. Words Used by Participants to Describe Their Concerns When Writing in English 
Words describing concerns in Portuguese writing

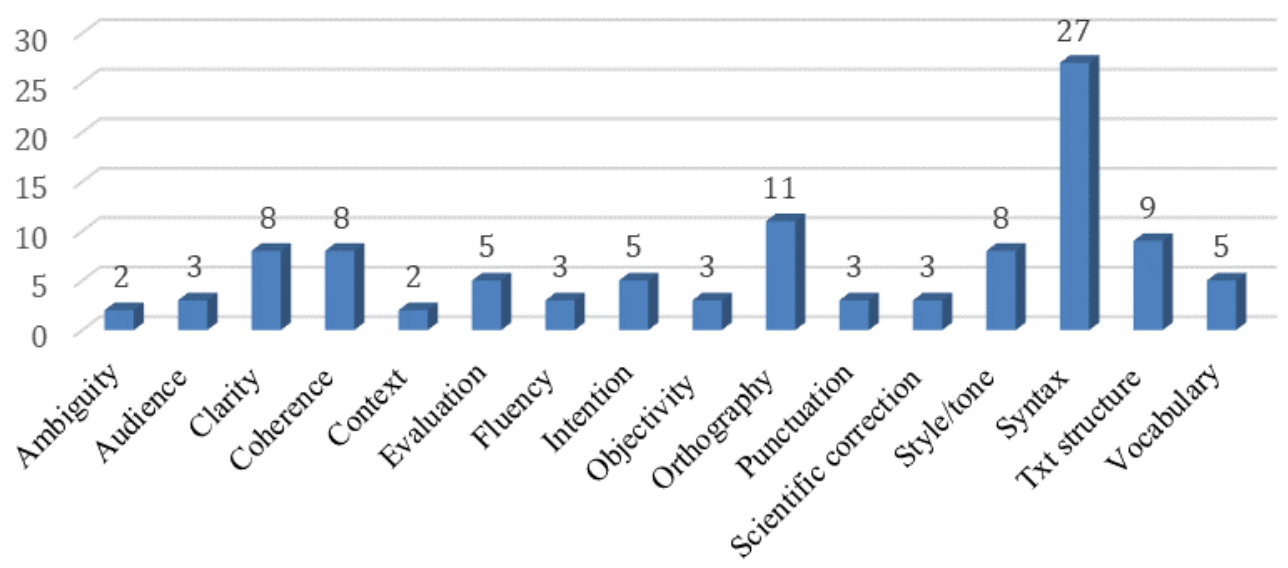

Figure 7. Words Used by Participants to Describe Their Concerns When Writing in Portuguese

Firstly, the analysis of the collected data indicates that 'Syntax' and 'Orthography' are the words most often mentioned by participants when asked to name their worries while in the process of writing in English and in Portuguese. 'Linguistic correction' and 'Syntax' were also indicated as the parameters that the participants thought their language professors would highly value when evaluating their writings.

Furthermore, results also show that respondents wrote very similar words to describe their own writing process irrespective of the language they use, English or Portuguese (figure 8). These results can be interpreted as consonant with the views stating that the writing process activates similar cognitive processes in both languages. In fact, when participants are asked to write the first three words that come to their minds when they think of what aspects they must attend to when writing in English or in Portuguese, the majority mentioned the same words to describe the dimensions they pay most attention when they are in process of composing in both languages.

Nevertheless, although identical, and except for the text unit 'Context', which shows the same lowest frequency of occurrences (2), or the text units 'Clarity', 'Coherence/cohesion' and 'intention', which are very close in the frequency number of occurrences for both languages (ranging from 2 to 8 occurrences in both languages), there are small differences in the frequency with which these words were used when participants referred to English or to Portuguese Writing. That is, the consideration of the existence of text 'Audience', the attention paid to their own language 'Fluency' and to 'Orthography' were the units more frequently used to refer to writing in English rather than in Portuguese. Similarly, the attention paid to the need to be scientifically correct and the concern with their teachers' evaluation of 'Text global structure' and 'Communicative intention' were also considered slightly more important in English rather than in Portuguese writing. However, participants considered the need to be 'objective', and the need to pay attention to 'Syntax' and to 'Text 
structure' more often when they referred themselves to the process of writing in Portuguese.

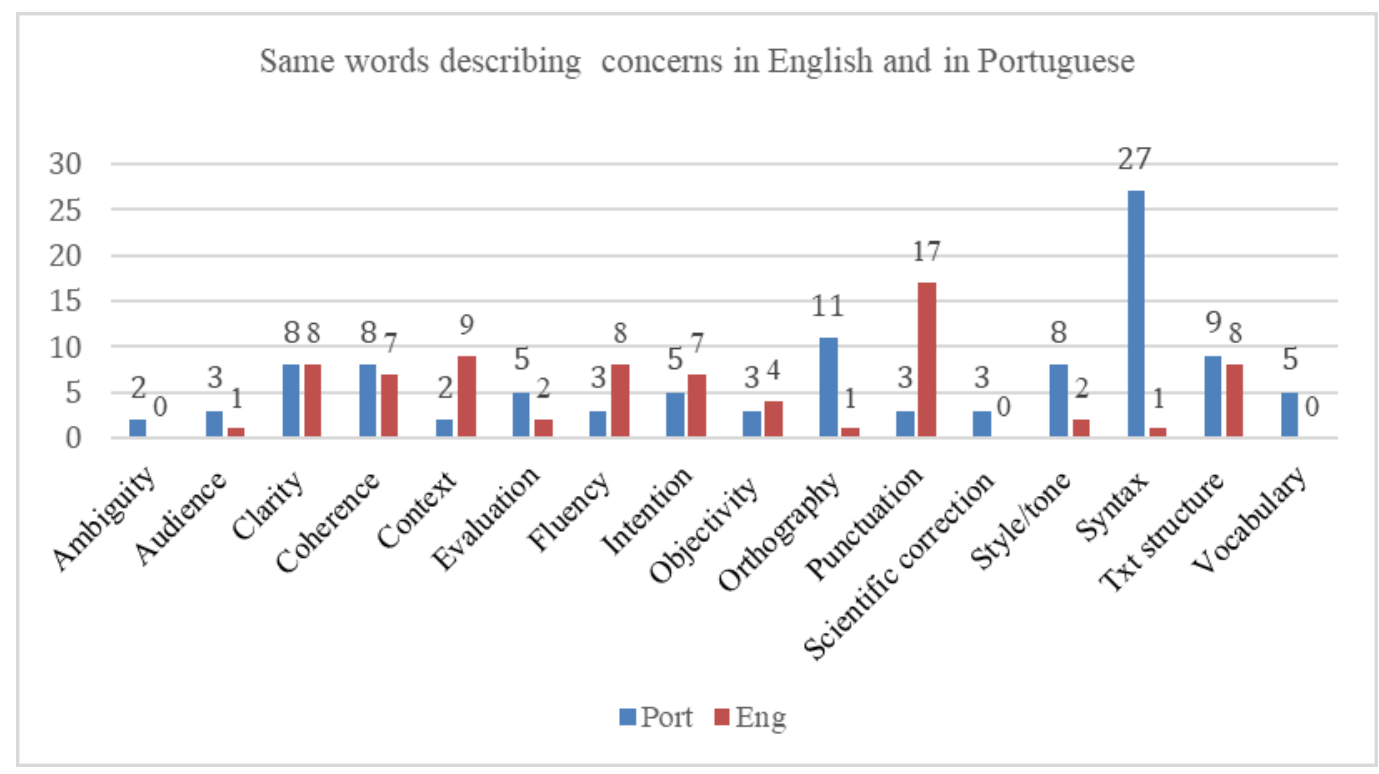

Figure 8. Same Words Describing Participants Concerns When Writing in English and in Portuguese

Text units such as 'Aesthetics', 'Redundancy', 'Register' and 'Topic choice' were only mentioned by a few respondents, when they considered their writing processes in English language. Text units like 'Ambiguity', 'Punctuation', Style/tone' and 'Vocabulary' were only mentioned by a few respondents when they considered their writing processes in Portuguese language. In addition, when the global data were analysed, these text units showed rather few occurrences when the respondents considered writing either in Portuguese or in English. The text unit 'Style/tone' was also only mentioned by 8 (22\%) participants when they referred themselves to the process of writing in Portuguese.

\section{Conclusions}

This study aimed at the description of the writing self-portrait of a group of Portuguese graduate students, the identification of their favourite procedures when writing either in the Portuguese or in the English language, as well as the analysis of their representations of their teachers' writing evaluation criteria. Results obtained with the analysis of the data collected allow us to present the following conclusions, which provide the answers to the research questions that guided this study.

The larger number of the respondents of this study are female social sciences students who do not see themselves as being highly competent in the English language, although they learned it for at least 5 years while in secondary school. Most of them naturally prefer to write their papers in Portuguese, their first language. Furthermore, they seem not to have been taught how to write in English during their formal education, and therefore they do not seem to be at 
ease with academic writing in English.

The global analysis of the collected data revealed subtle differences in the participants' answers to questions that inquired about their intuitions towards their writings' evaluation criteria when compared to their answers which focus on their own writing processes.

Findings reveal that their perceptions of the most valued parameters in the evaluation of their writings in English and in Portuguese place 'Linguistic correction', 'Text global structure' and 'Syntax' in the first place. These findings are in consonance with what teachers tend to focus when assessing their students' writings. Although we are all aware that choice of topic, context, and pragmatic conventions are the core issues of communicative approaches to teaching writing, the fact is, based on my students reports, that their teachers seem to mostly focus their evaluation on the linguistic aspects of their writings: orthography and syntax. (Cabral, 2018).

Results on the analyses of their answers concerning relevant dimensions to their own processes of composing and revising in Portuguese, as well as in English show that while a larger percentage of respondents mention 'Syntax' and 'Orthography' as their main concerns while revising their texts, it seems that when they are in the process of composing their main concerns are related to the choice of the research topic (which imply the knowledge of scientific terminology), and only afterwards with the 'Revising of sentence structure and linguistic correction'.

Style (level of formality) and tone (the attitude communicated through the choice of lexis) are two key aspects in academic writing, for they are related to the purpose and the appropriate conventions of the text intended to be written. Text organization, as well as punctuation, are additional relevant dimensions when one composes, since these aspects are germane to the readers' comprehension of the content exposed. The same can be said to clarity, which reveals the writer's ability to convey the relationship between ideas and arguments conveyed. However, findings reveal that "Context", "Objectivity", "Intention", 'Text global planning, genre and style' and 'Text structure' do not seem to be among the participants' $s$ immediate concern either while composing or revising their texts, in English or in Portuguese. They also indicate that they are less concerned with discursive aspects such as the 'Avoidance of frills, figures of speech and qualifiers', as well as with the 'Focus on the audience' when they are composing in English. When they write their papers in English they seem to be more worried with the 'Avoidance of subjective discourse and personal feelings'. They also bear in mind the need to use 'Simple active voice sentences', while they pay attention to the 'Canonical structure of the scientific text'. Although with fewer occurrences, they also seem to be more worried about the need to avoid 'Subjective discourse' as well as the use of 'Frills, rhetorical figures and qualifiers' when they write in Portuguese. The recommendation of the need to 'Focus on the audience' was found to be considered more important when writing in Portuguese rather than in English, but occurred more frequently to refer to English writing when participants were asked the first 3 words to come to their minds when describing their own writing process.

These findings lead to the conclusion that there are many similarities between both writing 
processes, in English and in Portuguese, and they seem to be supported by previous research findings on L1/L2 writing, for example, Matsumoto (1995), Kern (2000), Zainuddin \& Moore (2003), Uysal (2008), Kliber (2010).

However, findings also revealed there are subtle differences that may be related either to the participants' lower language ability or to their lower familiarity with writing in English. In consonance with van Weijen, et al., 2009, and de Larios, et al., 2006 findings, there seems to be differences in the participants' process of goal setting, which seems to be more relevant to them when writing in Portuguese rather than in English. Furthermore, similarly to what Silva, (1993), Casey (2006) and Manchon \& de Larios, (2007), and Wang (2012) have found, the participants in this study also seem to adopt slightly different composing and revising strategies when they write in English and in Portuguese.

Based on the results obtained, the participants of this study do not seem to have achieved the goals stated on the Portuguese and English language syllabi of basic and secondary schooling, which point to text structure, communicative intention, audience and content topic as the main goals in the teaching of language at the final years of the Portuguese secondary schooling process. In addition, they also seem to indicate that participants were not instructed on how to write academic papers in English during their higher education experience, or that they did not learn to value the parameters and dimensions that usually guide the teaching of academic writing in English.

In face of these findings, exploratory by nature, since there are no other published studies on Portuguese graduate perceptions on their own writing process, we believe that academic writing in Portuguese and English should be included in all language degrees at the universities. Students need to be made aware of the genre specificities of academic writing (e.g., genre, register, syntax, and text structure), and they also should be more encouraged to conceive writing as a process rather than a home one draft-product with the final intent of submitting it to their teachers' evaluation.

Academic writing, as any other writing task performed during higher education programmes, needs to be carefully planned by the teachers to provide students with the writing practices that contribute to the development of their language awareness and writing ability. Writing is an engaging activity that requires many individual resources (e.g., cognitive, linguistic, emotional, aesthetic). We only learn to write by practicing it writing regularly with the help (or under the supervision) of more mature writers: academic writing is no exception. If we intend to transform writing into a significant experience for the students (as well as for teachers), writing classes must be conceived as writing labs, where collaborative, meaningful and critical practices are not only allowed but also encouraged.

The times when language students came to the university already proficient in writing are over long ago. Luckily, for some decades, Portuguese universities have been accepting all kinds of students, with highly diverse cultural backgrounds. All of them have the right to complete their degrees with the knowledge and the competences they will need to be fully integrated in their social communities, as well as succeed in the global labour market. Writing in general and particularly academic writing are one of today's most relevant competences, 
particularly for Humanities' students.

\section{References}

Amor, E. (1993). Didáctica do Português: Fundamentos e metodologia. Lisboa: Texto Editores.

Anderson, R. (2007). Thematic Content Analysis (TCA). Descriptive Presentation of Qualitative Data. Document prepared for graduate students. Institute of Transpersonal Psychology. Palo Alto. California. Retrieved 31 August, 2015 from http://www.scribd.com/doc/107958813/Thematic-Content-Analysis\#scribd

Beare, S., \& Bourdages, J. S. (2007). Skilled writers' generating strategies in L1 and L2: An exploratory study. In Rijlaarsdam, G., \& Torrance, M., VanWaes, L., \& Galbraith, D. (Eds.), Writing and cognition: Research and applications, 151-161. Amsterdam: Elsevier.

Becker, H. S. (2007). Writing for social scientists. Chicago \& London: The University of Chicago Press.

Belcher, D. (2007). Seeking acceptance in an English-only research world. Journal of Second Language Writing, 16(1), 1-22. https://doi.org/10.1016/j.jslw.2006.12.001

Cabral, M. (1994). Avaliação e escrita: um processo integrado. In Fernanda Irene da Fonseca (Org.), Pedagogia da Escrita. Perspectivas. Porto: Porto Editora.

Cabral, M. L. (2004a). A escrita processual na aula de Inglês. Faro: CELL/FCHS.

Cabral, M. L. (2004b). Para o ensino da leitura e a escrita no ensino básico e no ensino superior. Faro: CELL/FCHS.

Cabral, M. L. (2018). EFL classroom notes. Faro: FCHS, University of Algarve.

Cabral, M. L. (2010). Temas de Didática das Línguas. Faro: CELL/FCHS.

Cabral, M. L., Costa, N. C., \& Nobre, A. M. (2016). The English language conquest of Portuguese academic writing: a study of faculty members' language choices. EILJ, 11(2), 77-107.

Candlin, C. N., \& Hyland, K. (1999). Writing: texts, processes and practices. London, UK: Routledge.

Casey, K. (2006). The use of paraphrase in summary writing: A comparison of L1 and L2 writers. Journal of Second Language Writing, 15(4), 261-278. https://doi.org/10.1016/j.jslw.2006.09.006

Connor, U. (1988). Research frontiers in writing analysis. In Silva, T., \& Matsuda, R. (Eds.), Landmark essays on ESL writing, 75-91. Mahwah, N. J.: Hermagoras Press.

De Larios, J. R., Manchon, R. M., \& Murphy, L. (2006). Generating text in native and 
foreign language writing: A Temporal analysis of problem-solving Formulation $\begin{array}{llll}\text { Processes. Modern } \quad \text { Language Journal, } & \text { 90(1), 100-114. }\end{array}$ https://doi.org/10.1111/j.1540-4781.2006.00387.x

Flowerdew, J. (2001). Attitudes of journal editors to non-native speaker contributions. TESOL Quarterly, 35, 121-150. https://doi.org/10.2307/3587862

Gabrialatos, C. (2002). EFL writing: Product and process. ERIC, ED476839.

Gosden, H. (2003). Why not give us the full story? Functions of referees' comments in peer reviews of scientific research papers. Journal of English for Academic Purposes, 2, 87-101. https://doi.org/10.1016/S1475-1585(02)00037-1

Grabe, W., \& Kaplan, R. (1996). Theory and Practice of Writing. Essex, UK: Longman.

Gradman, H. L., \& Hanania, E. (1991). Language learning background factors and ESL proficiency. The Modern Language Journal, 75(1), 39-51. https://doi.org/10.1111/j.1540-4781.1991.tb01081

Hinkel, E. (2002). Grammar teaching in writing classes: Tenses and cohesion. In Hinkel, E., \& Fotos, S. (Eds.), New perspectives on grammar teaching in second language classrooms. New Jersey: Lawrence Earlbaum Associates, Inc.

Kibler, A. (2010). Writing through Two Languages: First Language Expertise in a Language Minority Classroom. Journal of Second Language Writing, 19(3), 121-142. https://doi.org/10.1016/j.jslw.2010.04.001

Krashen, S., \& Lee, S-Y. (2002). Predictors of success in EFL writing: reading, revision behaviour, apprehension and writing. The College Student Journal, 36(4), 532-543.

Krashen, S. (2014). The Composing Process. Research Journal: Ecolint Institute of Teaching and Learning, 2, 20-30.

Lee, S. Y. (2001). What Makes It So Difficult to Write. Taipei: Crane Publishing Company.

Lee, Y. O., \& Krashen, S. (1996). Competence in foreign language writing: Progress and lacunae. OnCue Journal, 12(2), 10-14.

Lee, Y. O., Krashen, S., \& Gribbons, B. (1996). The effect of reading on the acquisition of English relative clauses. ITL: Review of Applied Linguistics, 263-273.

López-Urdaneta, J. L. (2011). Spanish-English Writing Structure Interferences in Second Language Learners. GIST - Education and Learning Research Journal, 5, 158-179.

Lu, Y. (2010). Cognitive Factors Contributing to Chinese EFL Learners' L2 Writing Performance in Timed Essay Writing. Dissertation Submitted in Partial Fulfilment of the Requirements for the Degree of Doctor of Philosophy in the College of Arts and Sciences Georgia State University.

Manchon, R. M., \& de Larios, J. R. (2007). On the temporal nature of planning in L1 and L2 composing. Language Learning, 57(4), 549-593. 
https://doi.org/10.1111/j.1467-9922.2007.00428.x

Matsumoto, K. (1995). Research paper writing strategies of professional Japanese EFL Writers. TESL Canada Journal, 13(1), 17-27. https://doi.org/10.18806/tesl.v13i1.658

Nelson, N., \& Castelló, M. (2012). Academic Writing and Authorial Voice. Studies in Writing, 24, 33-51. https://doi.org/10.1108/S1572-6304(2012)0000024007

Peironcely, J. (2008). 5 tips to improve your academic writing. Next Scientist. Retrieved 5 July, 2016 from http://www.nextscientist.com/tips-improve-your-academic-writing/

Programas de Inglês: $10^{\circ}, 11^{\circ}$ e $12^{\circ}$ anos. (2001-2003). Lisbon: DEB/Ministério da Educação.

Raimes, A. (1985). What unskilled ESL students do as they write: A classroom study of composition. In Silva, T., \& Matsuda, R. (Eds.), Landmark essays on ESL writing, 37-63. Mahwah, N. J.: Hermagoras Press.

Ritter, R. M. (2005). New Hart's rules: The handbook of style for writers and editors. Oxford: O.U.P.

Roca de Larios, J., Manchón, R., Murphy, L., \& Marín, J. (2008). The foreign language writer's strategic behaviour in the allocation of time to writing processes. Journal of Second Language Writing, 17(1), 30-47. https://doi.org/10.1111/0023-8333.00163

Santos, O. (1994). A escrita no ensino secundário. In Fernanda Irene da Fonseca (Org.), Pedagogia da Escrita. Perspectivas. Porto: Porto Editora.

Sasaki, M. (2002). Building an empirically-based model of EFL learners' writing processes. In Rijlaarsdam, G., \& Ransdell, S., \& Barbier, M. (Eds.), New directions for research in L2 Writing, 49-80. Dordrecht: Kluwer Academic Publishers.

Sasaki, M., \& Hirose, K. (1996). Explanatory variables for EFL students' expository writing. Language Learning, 46, 137-174. https://doi.org/10.1111/j.1467-1770.1996.tb00643.x

Siguan, M. (2001). Bilingüismo y lenguas en contacto. Madrid: Alianza Editorial.

Silva, T. (1993). Toward an Understanding of the Distinct Nature of L2 Writing: The ESL Research and Its Implications. TESOL Quarterly, 27(4), 57-677. https://doi.org/10.2307/3587400

Swales, J. (2002). Genre analysis. English in academic and research settings. Cambridge: C. U. P.

Swales, J., \& Feak, C. (2006). Academic writing for graduate students. Ann Arbor: The University of Michigan Press.

Tang, R. (Ed.). (2012). Academic writing in a second or foreign language. London: Bloomsbury Publishing.

Tom, A., Morni, A., \& Metom, L. (2013). Students' perceptions and preferences of written feedback in academic writing. Mediterranean Journal of Social Sciences, 4(11), 72-80. 
https://doi.org/10.5901/mjss.2013.v4n11p72

Trible, C. (1996). Writing. Oxford: O. U. P.

University of Bristol. (2012). Improve your writing. Retrieved from http://www.northumbria.ac.uk/skillsplus

University of Bristol. (2014). How to improve your academic writing. Retrieved 6 June, 2015 from https://www.northumbria.ac.uk/static/5007/llspdf/skills/academicwriting.pdf

University of Essex. (2012). How to improve your academic writing. Retrieved 6 June, 2015 from http://www.essex.ac.uk/myskills/Howto_improve_your_academic_writing.pdf

University of Wisconsin. (2014). UW-Madison Writer's Handbook. Retrieved from https://writing.wisc.eduHandbook/index.html. Retrieved 6 June 2015

Uysal, H. H. (2008). Tracing the culture behind writing: Rhetorical patterns and bidirectional transfer in L1 and L2 essays of Turkish writers in relation to educational context. Journal of Second Language Writing, 17(3), 183-207. https://doi.org/10.1016/j.jslw.2007.11.03

van Weijen, D., van den Bergh, H., Rijlaarsdam, G., \& Sanders, T. (2009). L1 use during L2 writing: An empirical study of a complex phenomenon. Journal of Second Language Writing, 18(4), 235-250. D https://doi.org/10.1016/j.jslw.2009.06.003.

Wang, Y. (2012). Differences in L1 and L2 academic writing. Theory and Practice in Language Studies, 2(3), 637-641. https://doi.org/10.4304/tpls.2.3.637-641

Zainuddin, H., \& Moore, R. A. (2003). Bilingual writers' awareness of audience in L1 and L2 persuasive writing. Retrieved 10 August, 2019 from ERIC database. (ED 476598). https://eric.ed.gov/?id=ED476598

\section{Copyright Disclaimer}

Copyright for this article is retained by the author(s), with first publication rights granted to the journal.

This is an open-access article distributed under the terms and conditions of the Creative Commons Attribution license (http://creativecommons.org/licenses/by/3.0/). 